\title{
Cultured Human Periosteum-Derived Cells Can Differentiate into Osteoblasts in a Perioxisome Proliferator-Activated Receptor Gamma-Mediated Fashion via Bone Morphogenetic Protein signaling
}

\author{
Jin-Eun Chung ${ }^{1}$, Jin-Ho Park ${ }^{1}$, Jeong-Won Yun ${ }^{1}$, Young-Hoon Kang ${ }^{1}$, Bong-Wook Park ${ }^{1}$, Sun-Chul

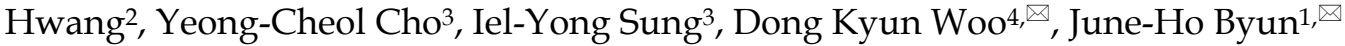 \\ 1. Department of Oral and Maxillofacial Surgery, Gyeongsang National University School of Medicine and Gyeongsang National University Hospital, \\ Institute of Health Sciences, Gyeongsang National University, Jinju 660-702, Republic of Korea \\ 2. Department of Orthopaedic Surgery, Institute of Health Sciences, Gyeongsang National University School of Medicine, Jinju, Republic of Korea \\ 3. Department of Oral and Maxillofacial Surgery, College of Medicine, Ulsan University Hospital, University of Ulsan, Ulsan, Republic of Korea \\ 4. College of Pharmacy and Research Institute of Pharmaceutical Sciences, Gyeongsang National University, Jinju, Republic of Korea
}

$\triangle$ Corresponding authors: June-Ho Byun (Department of Oral and Maxillofacial Surgery, Institute of Health Sciences, Biomedical center (BK21), 660-702, Gyeongsang National University School of Medicine, Jinju, Republic of Korea, Tel: 82-55-750-8258, Fax: 82-55-761-7024, E-mail address : surbyun@gsnu.ac.kr) or Dong Kyun Woo (College of Pharmacy and Research Institute of Pharmaceutical Sciences, Gyeongsang National University, Jinju, Republic of Korea, Tel: 82-55-772-2428, E-mail: dongkyun.woo@gnu.ac.kr)

(1) Ivyspring International Publisher. Reproduction is permitted for personal, noncommercial use, provided that the article is in whole, unmodified, and properly cited. See http://ivyspring.com/terms for terms and conditions.

Received: 2016.06.15; Accepted: 2016.09.13; Published: 2016.10.17

\begin{abstract}
The differentiation of mesenchymal stem cells towards an osteoblastic fate depends on numerous signaling pathways, including activation of bone morphogenetic protein (BMP) signaling components. Commitment to osteogenesis is associated with activation of osteoblast-related signal transduction, whereas inactivation of this signal transduction favors adipogenesis. BMP signaling also has a critical role in the processes by which mesenchymal stem cells undergo commitment to the adipocyte lineage. In our previous study, we demonstrated that an agonist of the perioxisome proliferator-activated receptor $\gamma$ (PPAR $\gamma)$, a master regulator of adipocyte differentiation, stimulates osteoblastic differentiation of cultured human periosteum-derived cells. In this study, we used dorsomorphin, a selective small molecule inhibitor of BMP signaling, to investigate whether BMP signaling is involved in the positive effects of PPARY agonists on osteogenic phenotypes of cultured human periosteum-derived cells. Both histochemical detection and bioactivity of ALP were clearly increased in the periosteum-derived cells treated with the PPAR $\gamma$ agonist at day 10 of culture. Treatment with the PPAR $\gamma$ agonist also caused an increase in alizarin red $\mathrm{S}$ staining and calcium content in the periosteum-derived osteoblasts at 2 and 3 weeks of culture. In contrast, dorsomorphin markedly decreased ALP activity, alizarin red S staining and calcium content in both the cells treated with PPAR $y$ agonist and the cells cultured in osteogenic induction media without PPAR $y$ agonist during the culture period. In addition, the PPAR $y$ agonist clearly increased osteogenic differentiation medium-induced BMP-2 upregulation in the periosteum-derived osteoblastic cells at 2 weeks of culture as determined by quantitative reverse transcriptase polymerase chain reaction (RT-PCR), immunoblotting, and immunocytochemical analyses. Although further study will be needed to clarify the mechanisms of PPARY-regulated osteogenesis, our results suggest that the positive effects of a PPARY agonist on the osteogenic phenotypes of cultured human periosteum-derived cells seem to be dependent on BMP signaling.
\end{abstract}

Key words: Periosteum-derived cells; Osteoblastic differentiation; PPARY agonist; BMP signaling 


\section{Introduction}

The differentiation of mesenchymal stem cells is largely dependent on a complex interplay of extracellular signaling molecules such as growth factors, hormones, and nutrients, that govern cell fate determination and switching. In normal bone, continuous osteoblastogenesis is maintained while adipogenesis appears to be suppressed. A precursor cell type that is differentiating along a specific cell lineage can be switched by genetic reprogramming into another cell type of a different lineage. Such fate decisions are regulated in part by lineage-specific transcription factors. The key transcription factors runt-related transcriptional factor 2 (Runx2) and perioxisome proliferator-activated receptor $\gamma$ (PPAR $\gamma)$ act as molecular switches to direct the differentiation of precursor cells into osteoblasts or adipocytes, respectively. The shift in mesenchymal stem cell differentiation to favor the adipocyte lineage over the osteoblast lineage directly contributes to imbalances in bone formation and resorption, and ultimately leads to bone loss [1-5].

PPARY is very specific to adipogenic differentiation and is induced before transcriptional activation of most adipocyte genes. PPARY is, therefore, well established as a prime regulator that stimulates adipogenesis in multipotent mesenchymal stem cells. In humans, administration of PPARY agonists results in progressive bone loss and diminished levels of circulating bone formation markers in older women. Additionally, PPARY agonists increase the rate of fracture in diabetic human subjects. Therefore, PPARY could serve as a useful target for drugs intended to enhance bone mass [6-9].

However, the effects of PPARY agonists on the differentiation of cultured osteoprecursor cells are still controversial. In mouse MC3T3-E1 osteoblasts, activation of PPAR $y$ with low doses of agonists stimulated alkaline phosphatase (ALP) activity and mineralization, whereas higher PPARY activator concentrations reduced ALP activity and calcium content. Overexpression of PPARY in C3H10T1/2 mouse mesenchymal precursors not only promotes adipogenic differentiation but also enhances osteogenic differentiation. In human bone marrow-derived mesenchymal stem cells, PPARY inhibitors reduce the extent of adipogenesis, but do not significantly influence expression of the major osteogenic transcription factor Runx2 [10-12].

Bone morphogenetic proteins (BMPs) belong to the transforming growth factor (TGF)- $\beta$ superfamily and play important roles in the induction of bone formation. BMPs bind to dimeric receptor complexes comprising types I and II transmembrane serine/threonine kinase receptors and induce an intracellular signal that upregulates a cascade of intracellular events. The receptors form homomeric and heteromeric complexes in distinct membrane areas and are differentially modulated by their ligands. Signal transduction via the receptors results in mobilization of members of the Smad family of proteins. The Smad pathway is initiated by the phosphorylation of regulatory Smad1/5/8, which associates with the common mediator Smad (Smad4), translocates into the nucleus, and regulates the transcription of various target genes such as ALP, Runx2, and osteocalcin by recruiting additional activators and repressors. These events induce differentiation of progenitor cells into chondrocytes and osteoblasts [13-16].

Our previous results suggested that the PPAR $\gamma$ agonist pioglitazone stimulates osteoblastic differentiation of cultured human periosteum-derived cells by increasing Runx 2 and ALP mRNA expression, and increasing mineralization. On the other hand, PPAR $\gamma$ antagonist T0070907 inhibits osteoblastic differentiation of the periosteum-derived cells by decreasing ALP expression and mineralization [17]. Considering the fact that several BMPs, in coordination with other signaling molecules, have been shown to stimulate preadipocyte differentiation, we hypothesized that the PPARY agonist enhances osteoblastic differentiation of cultured human periosteum-derived cells by activating BMP signaling $[18,19]$. To our knowledge, there is limited evidence regarding the effects of PPARY agonists on BMP signaling during osteoblastic differentiation of cultured osteoprecursor cells. The purpose of this study was to examine whether BMP signaling is involved in the positive effects of PPARY agonists on osteogenic phenotypes of cultured human periosteum-derived cells.

\section{Materials and Methods}

\section{Culture and differentiation of periosteum-derived cells}

Patients provided informed consent for collection of periosteal tissues, as required by the Ethics Committee of Gyeongsang National University Hospital (GNUH 2014-05-012). Periosteal explants $(5 \times 20 \mathrm{~mm})$ were harvested from mandibles during surgical extraction of impacted lower third molars. Periosteal pieces were cultured at $37^{\circ} \mathrm{C}, 95 \%$ humidified air, and 5\% $\mathrm{CO}_{2}$ in 100-mm culture dishes 
containing Dulbecco's Modified Eagle's Medium (DMEM) supplemented with $10 \%$ heat-inactivated fetal bovine serum (FBS), $100 \mathrm{IU} / \mathrm{mL}$ penicillin, and $100 \mu \mathrm{g} / \mathrm{mL}$ streptomycin. Upon reaching 90\% confluence, adherent cells were passaged by gentle trypsinization and reseeding in fresh medium. Osteoblastic differentiation was induced by culture of passage three periosteal cells in an osteogenic induction medium comprised of DMEM supplemented with $10 \% \mathrm{FBS}, 50 \mu \mathrm{g} / \mathrm{ml}_{\mathrm{L}}$-ascorbic acid 2-phosphate, $10 \mathrm{mM}$ dexamethasone, and $10 \mathrm{mM}$ $\beta$-glycerophosphate at a density of $3 \times 10^{4}$ cells/well in 24-well plates. Cells were differentiated for 21 days, with media changed every 3 days.

\section{Treatment of periosteum-derived osteoblastic cells with PPARY agonists and antagonists}

Periosteal cells that had been cultured in osteogenic induction medium were treated with 5 and $10 \mu \mathrm{M}$ concentrations of either PPAR $\gamma$ agonist pioglitazone or PPARY antagonist T0070907 (all from R\&D Systems, Minneapolis, MN, USA). Media were changed every 3 days, and the PPARY agonist or antagonist was also added at each change of the medium.

\section{Transient transfection and luciferase assay}

Transcriptional factor Runx2 is a critical regulator of osteoblast differentiation. The binding of nuclear Runx2 to osteoblast-specific elements up-regulates skeletal genes and consequently the osteoblast phenotype $[20,21]$. To examine the functional role of PPARY on Runx 2 activity in the periosteum-derived cells, the effects of the overexpression of Runx2 combined with PPARY agonist or PPARY antagonist were evaluated in confluent monolayers of periosteum-derived cells that were transiently transfected with a p6xOSE2-Luc reporter plasmid and Runx2 expression plasmid vector.

The periosteum-derived cells were transfected using TurboFect transfection reagent (Thermo Fisher Scientific, Fair Lawn, NJ, USA) according to the manufacturers' recommendations. The periosteumderived cells were cultured in six-well plates at a density of $1 \times 10^{5}$ cells/well for $16 \mathrm{~h}$ and then transfected with the p6xOse2-Luc $(2 \mu \mathrm{g} /$ well $)$ reporter plasmid and the Runx2 expression plasmid (2 $\mu \mathrm{g}$ /well) in serum-free medium. Six hours later, the medium was replaced with medium containing $10 \%$ FBS, and the cells were cultured overnight. The transfected cells were treated with different concentrations of PPARY agonist and PPARY antagonist for an additional $24 \mathrm{~h}$ in 10\% FBS containing DMEM. The cell lysates were prepared with reporter passive lysis buffer (Promega, Madison, WI, USA), and luciferase activity was determined with the Luciferase Assay System kit (Promega, Madison, WI, USA). The luciferase activity was normalized with respect to the protein content as determined by the BCA protein assay kit (Pierce Chemical Co., Rockford, IL, USA). Luminescence was measured using an AutoLumat LB953 instrument (EG\&G Berthold, Wallac, Finland).

\section{Effects of Smad pathway inhibitor (Dorsomorphin) on in vitro osteoblastic phenotypes of periosteum-derived cells treated with PPAR $\boldsymbol{\gamma}$ agonist and antagonist}

It is well known that BMPs modulate osteoblast differentiation by stimulating osteoblast-related transcriptional factors, including Run $x 2$, and that BMPs and Runx2 interact cooperatively to stimulate osteoblast gene expression. Dorsomorphin (6-[4-(2-piperidin-1-yl-ethoxy)phenyl]-3-pyridin-4-ylpyrazolo[1,5-a]pyrimidine), also known as compound $\mathrm{C}$, inhibits BMP signaling via the Smad pathway by targeting BMP receptors [13,22-24]. To investigate whether PPARY agonists stimulate osteoblastic phenotypes of periosteum-derived osteoblasts by activating BMP signaling, we examined the expression of typical osteogenic early and late markers in the cells treated with a PPARY agonist, following pretreatment with the BMP signaling inhibitor dDorsomorphin.

ALP expression and mineralized nodule formation are the key factors to determine osteoblast differentiation. ALP is an early marker for osteoblast differentiation, whereas, calcium content and matrix mineralization are associated with the endpoint of full maturation of the osteoblast phenotype [19]. The periosteum-derived cells were pretreated with $2 \mu \mathrm{M}$ dorsomorphin (Sigma-Aldrich, St. Louis, MO, USA) and then treated with either 5 and $10 \mu \mathrm{M}$ concentrations of the PPARY agonist pioglitazone or 5 and $10 \mu \mathrm{M}$ concentrations of the PPARY antagonist. ALP staining and activity, alizarin red $S$ staining and quantification, and calcium content were examined using a previously published method $[19,25]$.

The cells were stained with fast 5-bromo-4-chloro-3-indolyl phosphate and nitroblue tetrazolium (BCIP/NBT) alkaline phosphatase substrate (Amresco LLC, Solon, OH, USA) or 2\% alizarin red $\mathrm{S}$ solution for histochemical detection of ALP and alizarin red S, respectively. The ALP activity was determined using $50 \mathrm{mmol} / \mathrm{L}$ p-nitrophenylphosphate in a glycine- $\mathrm{NaOH}$ buffer at $\mathrm{pH}$ 10.4. The amount of $\mathrm{p}$-nitrophenylphosphate released was estimated by measuring the absorbance at $410 \mathrm{~nm}$. The ALP activities were normalized to the 
cellular DNA content using a PicoGreen dsDNA quantitation kit (Molecular Probes, Eugene, OR, USA) according to the manufacturer's instructions. Staining and activity determinations for ALP were performed at day 10 of culture, whereas determinations of alizarin red S staining were made at days 14 and 21 of culture.

Periosteum-derived osteoblastic cells were decalcified with $0.6 \mathrm{~N} \mathrm{HCl}$ for $24 \mathrm{~h}$ at room temperature for the calcium deposition assay. The calcium content of supernatants was determined by spectrophotometry using the o-cresolphthalein method (Calcium C-test Wako, Wako Pure Chemical Industries, Osaka, Japan). After decalcification, the total protein content in the supernatants was measured using a BCA protein assay kit (Pierce Chemical Co, IL, USA). Cellular calcium content was normalized to total protein content. Calcium content was also examined at days 14 and 21 of culture.

\section{Reverse transcription-polymerase chain reaction (RT-PCR) analyses}

Quantitative RT-PCR for BMP-2 was performed with total RNA extracted from periosteum-derived osteoblastic cells at indicated times. First-strand cDNA was generated using random hexamer primers provided in the first-strand cDNA synthesis kit (Applied Biosystems Inc., Waltham, MA, USA). Primers and probes [glyceraldehyde 3-phosphate dehydrogenase (GAPDH) Cat. \#Hs02758991-g1; BMP-2 Cat. \#Hs00154192-m1] were obtained commercially (TaqMan ${ }^{\circledR}$ Gene Expression Assay Kit, Applied Biosystems Inc., USA) and amplified using the same kit and following the manufacturer's instructions (TaqMan ${ }^{\circledR}$ Gene Expression Assay kit, Gene Expression Master Mix, Applied Biosystems Inc.). Amplification conditions were as follow: $50^{\circ} \mathrm{C}, 2$ $\mathrm{min} ; 95^{\circ} \mathrm{C}, 10 \mathrm{~min}$; followed by 40 cycles of $94^{\circ} \mathrm{C}, 15 \mathrm{~s}$ and $60{ }^{\circ} \mathrm{C}, 1 \mathrm{~min}$ in 96-well plates using the ViiA ${ }^{\mathrm{TM}} 7$ Real-Time PCR System (Applied Biosystems Inc.). Glyceraldehyde 3-phosphate dehydrogenase (GAPDH) was used as an internal control. All experiments were performed in triplicate. Quantitative RT-PCR for BMP-2 was examined at 2 weeks of culture.

\section{Immunoblotting of BMP-2}

Detection of BMP-2 in periosteal cells that had been cultured with PPARY agonists and antagonists was accomplished by lysing the cells in NP-40 lysis buffer [20 mM Tris, pH 7.5, $140 \mathrm{mM} \mathrm{NaCl}, 1 \mathrm{mM}$ EDTA, 1\% (v/v) Nonidet P-40, $5 \mu \mathrm{M}$ AEBSF, $1.5 \mathrm{nM}$ aprotinin, $10 \mathrm{nM}$ E-64, $10 \mathrm{nM}$ leupeptin] for $30 \mathrm{~min}$ and then sonicating and centrifuging the samples. The resultant supernatants were treated with $20 \%$ trichloroacetic acid for $20 \mathrm{~min}$ at $4^{\circ} \mathrm{C}$, followed by centrifugation.at $31,000 \times \mathrm{g}$ for $20 \mathrm{~min}$. Pellets were washed with $-20^{\circ} \mathrm{C}$ acetone, centrifuged at $31,000 \times \mathrm{g}$ for $30 \mathrm{~min}$, air dried, and resuspended in NP-40 lysis buffer. Proteins, which were resolved by sodium dodecyl sulfate-polyacrylamide gel electrophoresis (SDS-PAGE) and transferred to a nitrocellulose membrane, were probed with anti-BMP-2 antibody (Cat No.: ab14933sc-271529, Abcam plc, Cambridge, UK). Detection of BMP-2 expression was performed after 14 days of culture.

\section{Immunocytochemical analysis}

After 2 weeks of cell culture, immunocytochemical staining was conducted to visualize expression of BMP-2 in the periosteum-derived cells that had been treated with $10 \mu \mathrm{M}$ PPAR $\gamma$ agonist and antagonist. To perform the staining, the cells were rinsed with phosphate-buffered saline (PBS) and fixed with $4 \%$ paraformaldehyde in PBS for $20 \mathrm{~min}$, and then permeabilized with PBS containing $0.1 \%$ Triton X-100 (0.1\% PBST). The cells were incubated with BMP-2 (1:100 dilution, R\&D Systems, Minneapolis, MO, USA) for $12 \mathrm{~h}\left(4^{\circ} \mathrm{C}\right)$. Subsequently, the cells were incubated with FITC-conjugated goat anti-mouse IgG H\&L (1:200 dilution, Abcam plc, Cambridge, UK) secondary antibody for $1 \mathrm{~h}$ (room temperature). For nuclear staining, 4',6-diamidino-2-phenylindole (DAPI; Vector Laboratories, Burlingame, CA, USA) was added to each well. Immunocytochemical images were obtained using a confocal microscope (LSM 700, Carl Zeiss, Germany).

\section{Statistical analysis}

Each experiment was performed independently at least three times. One of the three independent experiments is shown as representative data. Data are expressed as mean \pm standard deviation. Statistical analyses were computed using GraphPad Prism software (GraphPad Software, La Jolla, CA, USA). Data were evaluated using one-way analysis of variance (ANOVA) with Tukey's multiple comparison and the Mann-Whitney test. Comparisons with $p<0.05$ were considered statistically significant.

\section{Results}

\section{Transcriptional activity of Runx2 by PPARY agonist and antagonist}

PPAR $\gamma$ agonist pioglitazone clearly enhanced the Runx2 transcriptional activity in periosteum-derived cells, whereas the PPAR $\gamma$ antagonist T0070907 significantly decreased the transcriptional activity of Runx2 in these cells (Fig. 1). Considering the transcriptional factor Runx2 plays a key role in 
osteoblast differentiation and function, this result suggests that the effects of PPAR $\gamma$ agonists on the in vitro osteoblastic differentiation of cultured human periosteal-derived cells also appear to be dependent of Runx2.

A

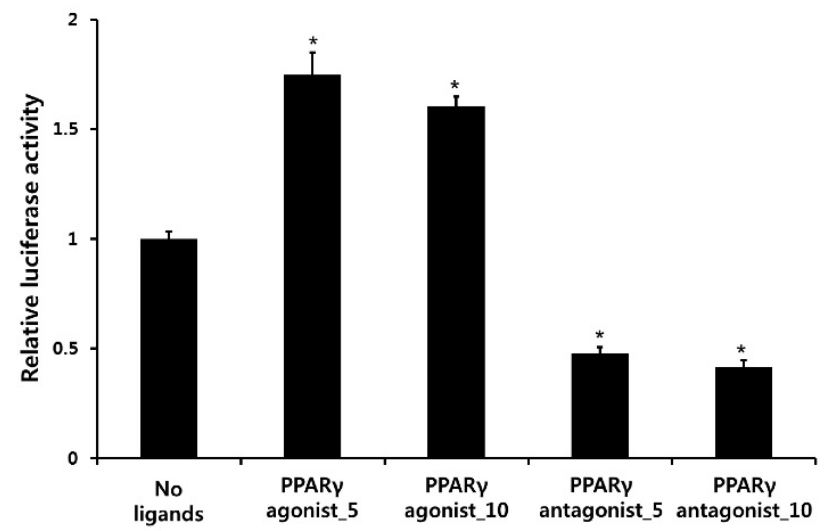

Figure 1. Activation of the transcriptional activity of Runx 2 by PPAR $\gamma$ agonist (pioglitazone) and antagonist (T0070907). *p<0.05 versus values observed in periosteum-derived cells without PPARY agonist and antagonist treatment.

\section{Histochemical detection and bioactivity of ALP in periosteum-derived cells treated with PPARY agonist (pioglitazone) and antagonist (T0070907) and Smad pathway inhibitor (dorsomorphin)}

After culturing cells for 10 days, both histochemical detection and bioactivity of ALP were clearly increased in the periosteum-derived cells treated with the PPAR $\gamma$ agonist. Both 5 and $10 \mu \mathrm{M}$ concentrations of the PPAR $\gamma$ antagonist markedly decreased ALP expression and bioactivity at day 10 of culture. Dorsomorphin significantly decreased ALP staining and bioactivity in the periosteum-derived cells treated with the PPAR $\gamma$ agonist and the cells cultured in osteogenic induction media without PPAR $\gamma$ agonist or antagonist at day 10 of culture. On the other hand, dorsomorphin seemed to decrease histochemical detection of ALP in the periosteum-derived osteoblastic cells treated with PPAR $\gamma$ antagonists; however, ALP bioactivity did not show a clear decrease in activity when the cells were treated with the PPAR $\gamma$ antagonist, following pretreatment of dorsomorphin at day 10 of culture (Fig. 2). Given the dorsomorphin is a selective small molecule inhibitor of BMP signaling, these data suggest that the effects of PPAR $\gamma$ agonists on the ALP activity in cultured human periosteal-derived osteoblastic cells seem to be dependent on BMP signaling.
Alizarin red S staining and calcium quantification in periosteum-derived osteoblasts treated with PPAR $y$ agonist (pioglitazone) and antagonist (T0070907) and Smad pathway inhibitor (dorsomorphin)

The PPAR $\gamma$ agonist at 5 and $10 \mu \mathrm{M}$ seemed to increase alizarin red-positive mineralization in the periosteum-derived osteoblasts, whereas the PPAR $\gamma$ antagonist at 5 and $10 \mu \mathrm{M}$ clearly decreased alizarin red S staining in the cells at 2 and 3 weeks of culture. Although $10 \mu \mathrm{M}$ PPAR $\gamma$ agonist did not significantly increased calcium content in the periosteum-derived osteoblasts, the PPAR $\gamma$ agonist clearly increased the quantification of alizarin red-positive mineralization and calcium content in the periosteum-derived osteoblasts at 2 weeks of culture. After 3 weeks of culture, the PPAR $\gamma$ agonist pioglitazone did not significantly increase the quantification of alizarin red $\mathrm{S}$ staining in the periosteum-derived osteoblasts, but significantly increased the calcium content in the cells. On the other hand, PPAR $\gamma$ antagonists markedly decreased the quantification of alizarin red-positive mineralization and calcium content in the periosteum-derived osteoblasts at 2 and 3 weeks of culture. Dorsomorphin visibly decreased alizarin red-positive mineralization in the periosteum-derived osteoblasts treated with PPAR $\gamma$ agonist or cultured in osteogenic induction media without PPAR $\gamma$ agonist or antagonist, whereas it did not seem to affect the alizarin red-positive mineralization in the cells treated with PPAR $\gamma$ antagonists at 2 and 3 weeks of culture.

Similar to the effects of dorsomorphin on ALP activity in the persioteum-derived cells treated with PPARY agonists or cultured in osteogenic induction media without PPARY ligands, the dorsomorphin significantly decreased alizarin red $S$ staining and calcium content in these cells treated with or without PPARY agonist at 2 and 3 weeks of culture. Although the quantification of alizarin red-positive mineralization clearly decreased in the cells treated with PPARY antagonists following pretreatment of dorsomorphin at 3 weeks of culture, dorsomorphin did not seem to affect alizarin red $S$ staining and calcium content in the periosteum-derived osteoblasts treated with PPARY antagonist at 2 and 3 weeks of culture (Fig. 3). Considering the fact that dorsomorphin inhibits BMP-mediated SMAD1/5/8 phosphorylation, these data suggest that the effects of PPARY agonists on mineralization in cultured human periosteum-derived osteoblasts appear to be dependent on BMP signaling.

Quantitative RT-PCR, immunoblotting and immunocytochemical analysis of BMP-2

The data of in vitro osteoblastic phenotypes of 
periosteum-derived osteoblastic cells treated with PPARY agonist and antagonist and dorsomorphin suggest that the effects of PPAR $\gamma$ agonists on the cells seem to be dependent of BMP signaling. We therefore

A

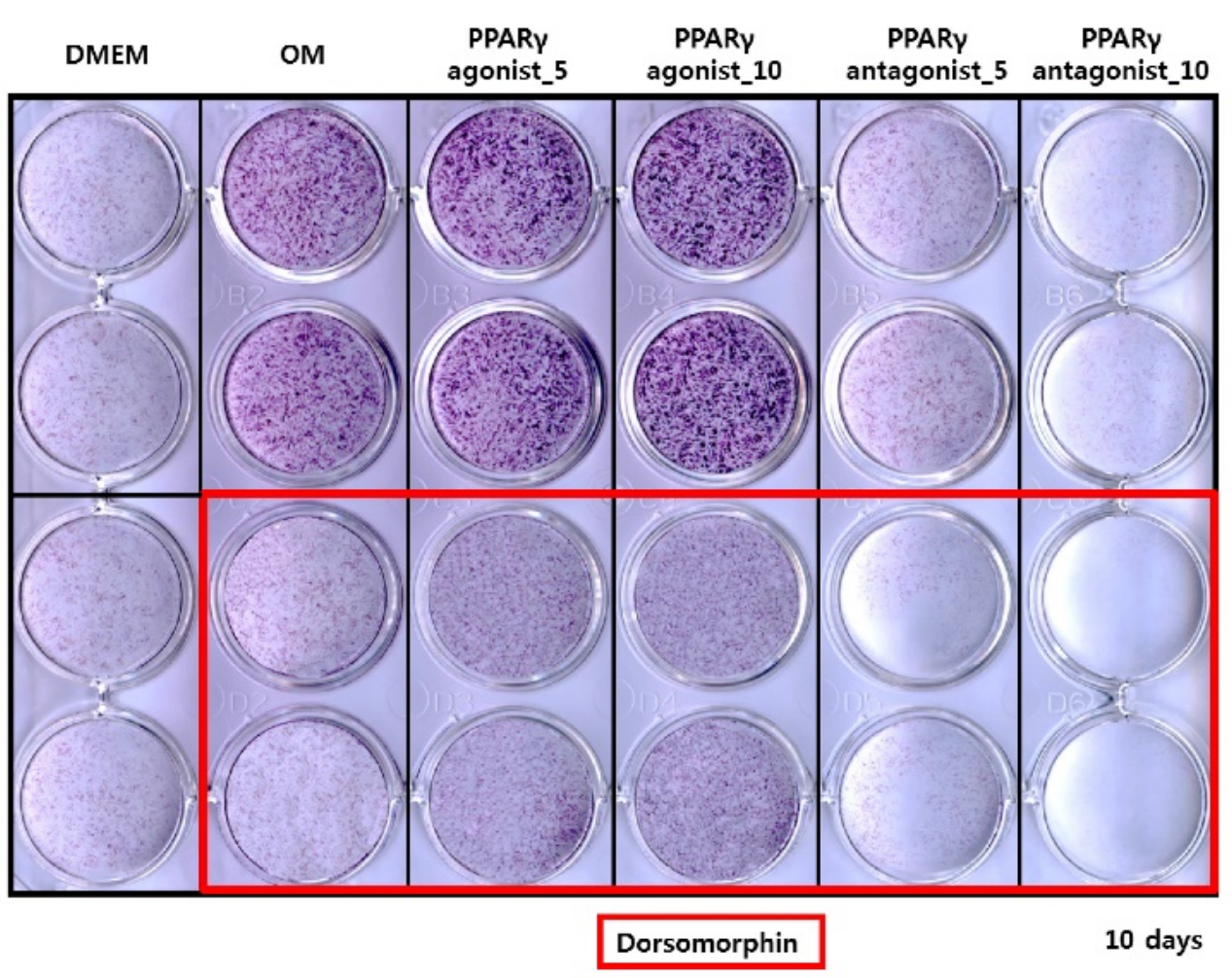

B examined the expression of BMP-2 in the periosteum-derived osteoblasts treated with PPAR $\gamma$ agonist and antagonist. BMP-2 is the most frequently studied ligand of BMPs that promotes osteogenic commitment and terminal osteogenic differentiation in mesenchymal stem cells [26].

Figure 2. Histochemical staining and bioactivity of ALP activity in periosteum-derived cells differentiated in osteoblastic induction media (OM) and treated with PPAR $\gamma$ agonist and antagonist and dorsomorphin. $* \mathrm{p}<0.05$ versus values observed in periosteum-derived cells cultured in OM without PPAR $\gamma$ agonist or antagonist treatment or versus cells cultured in OM without dorsomorphin.

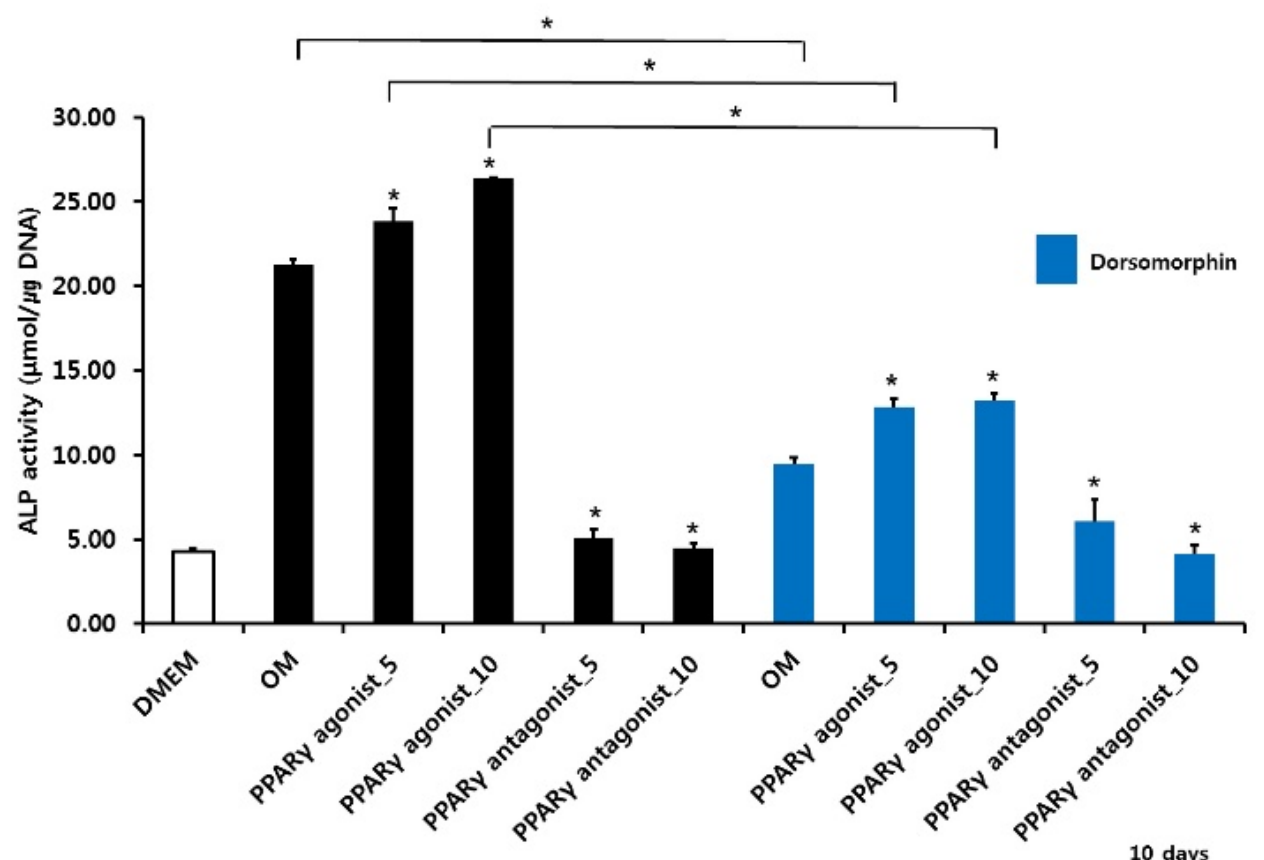


A

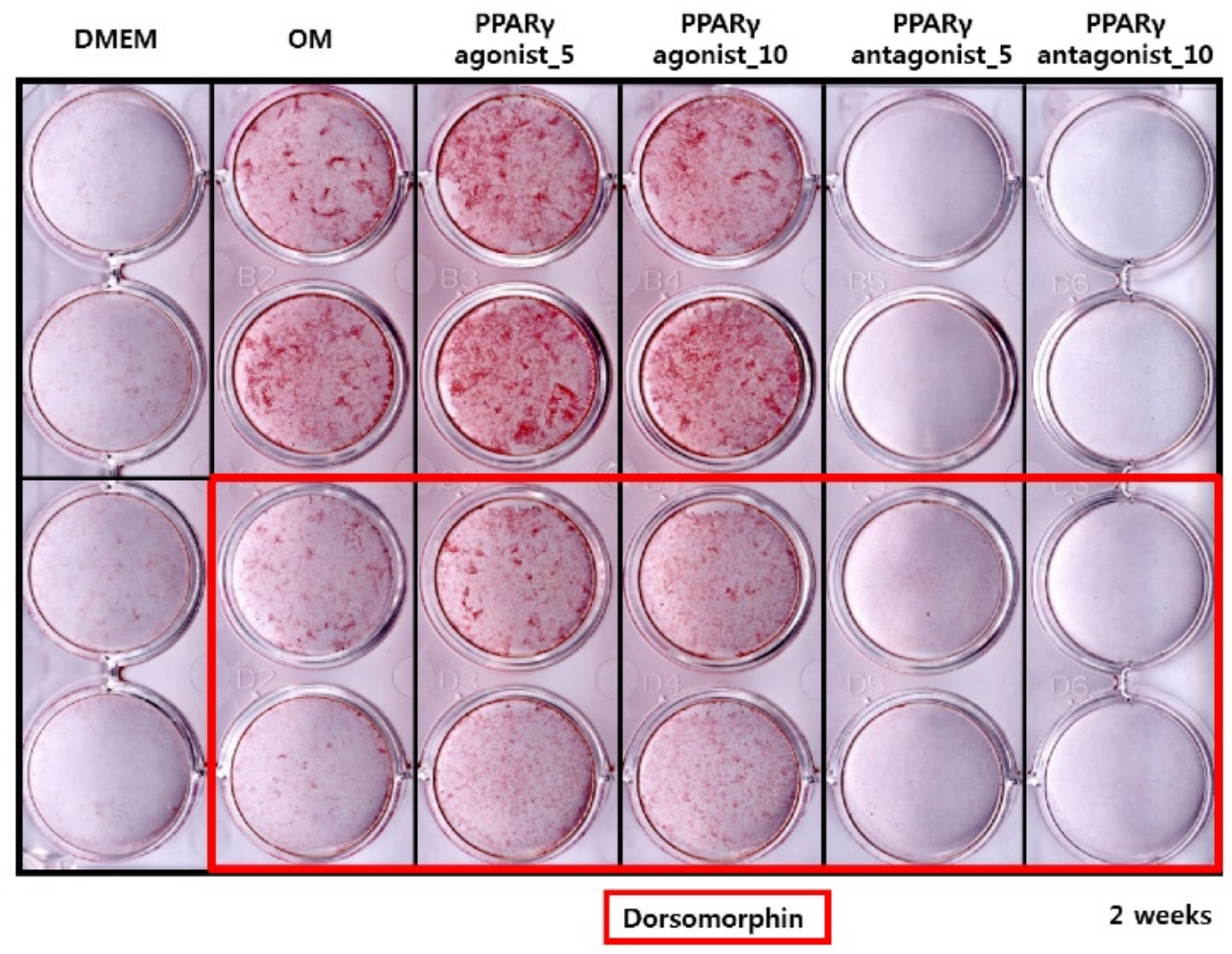

B

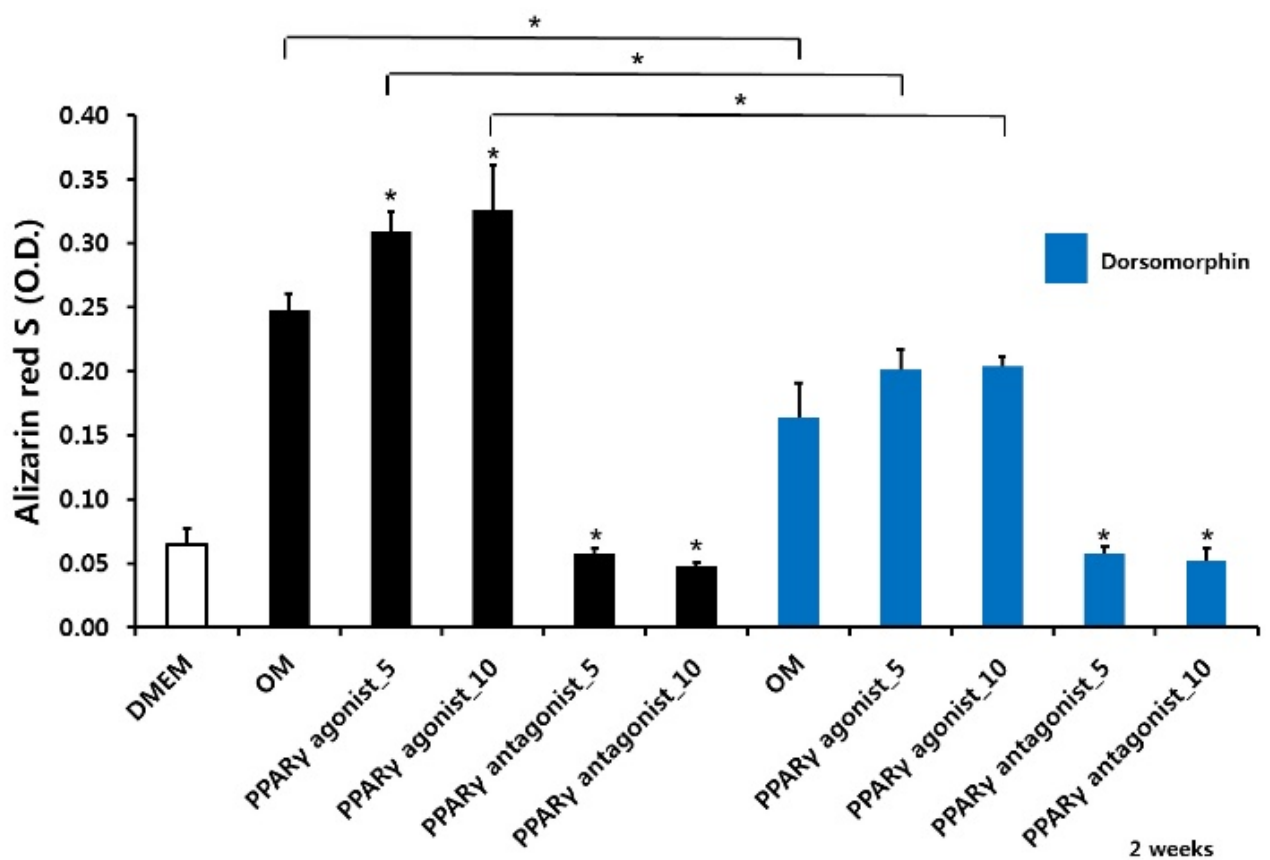


C

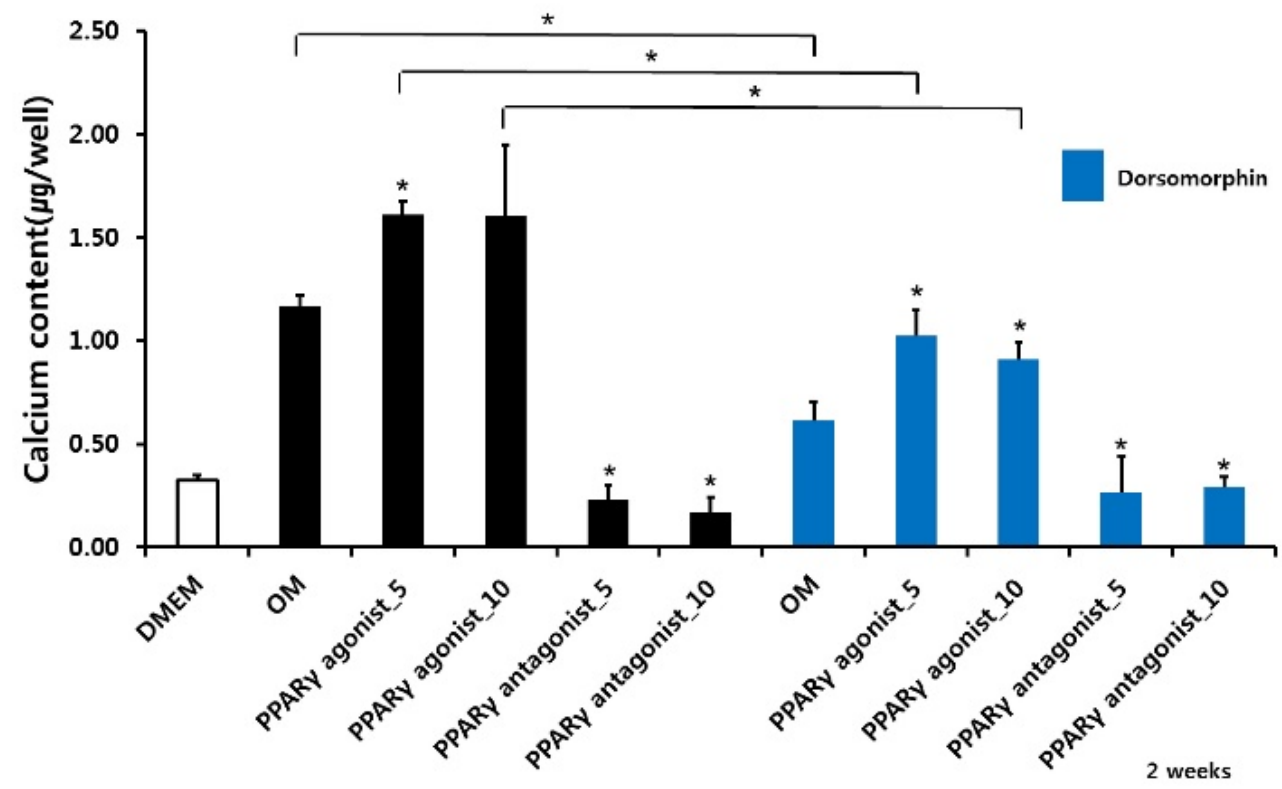

D

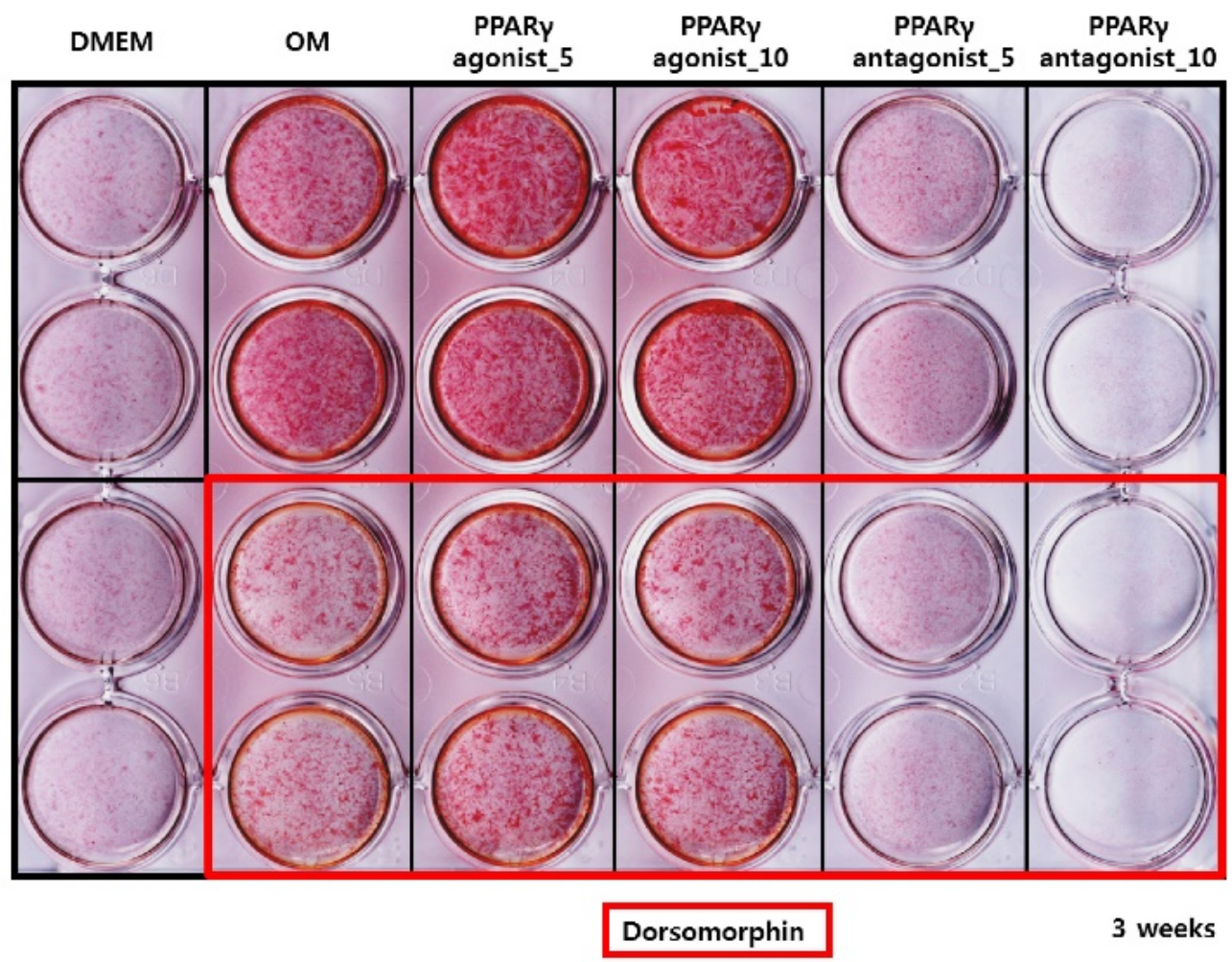


E

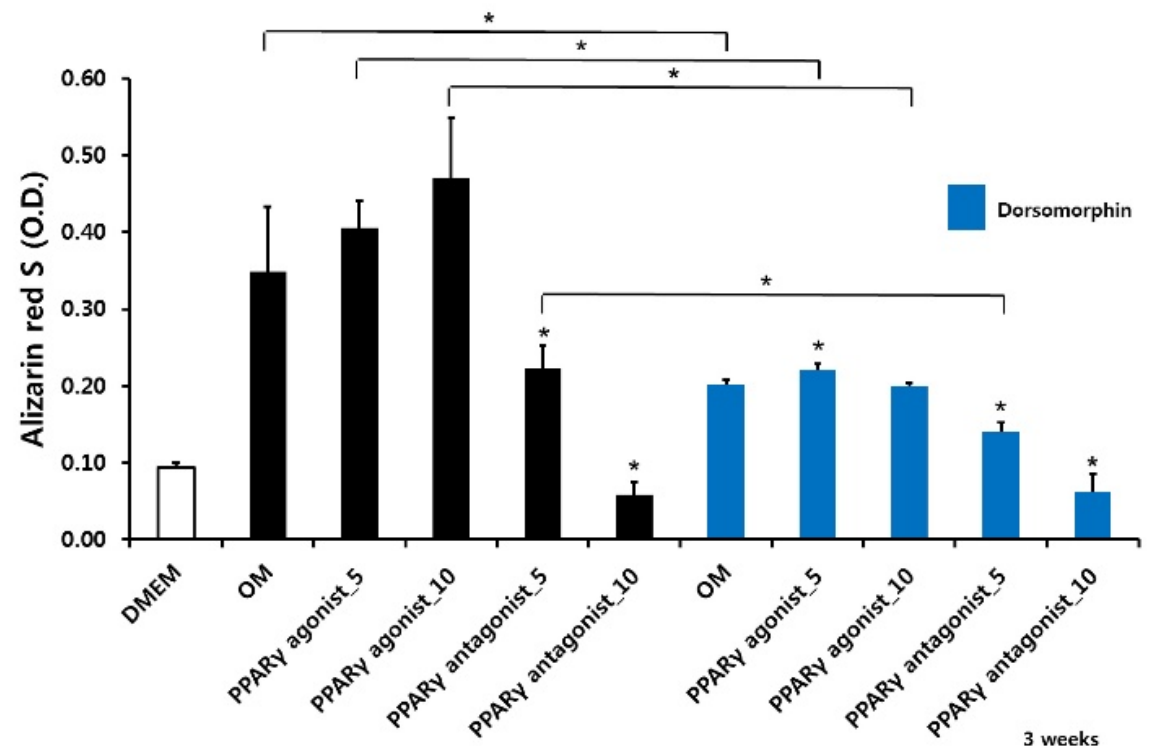

F

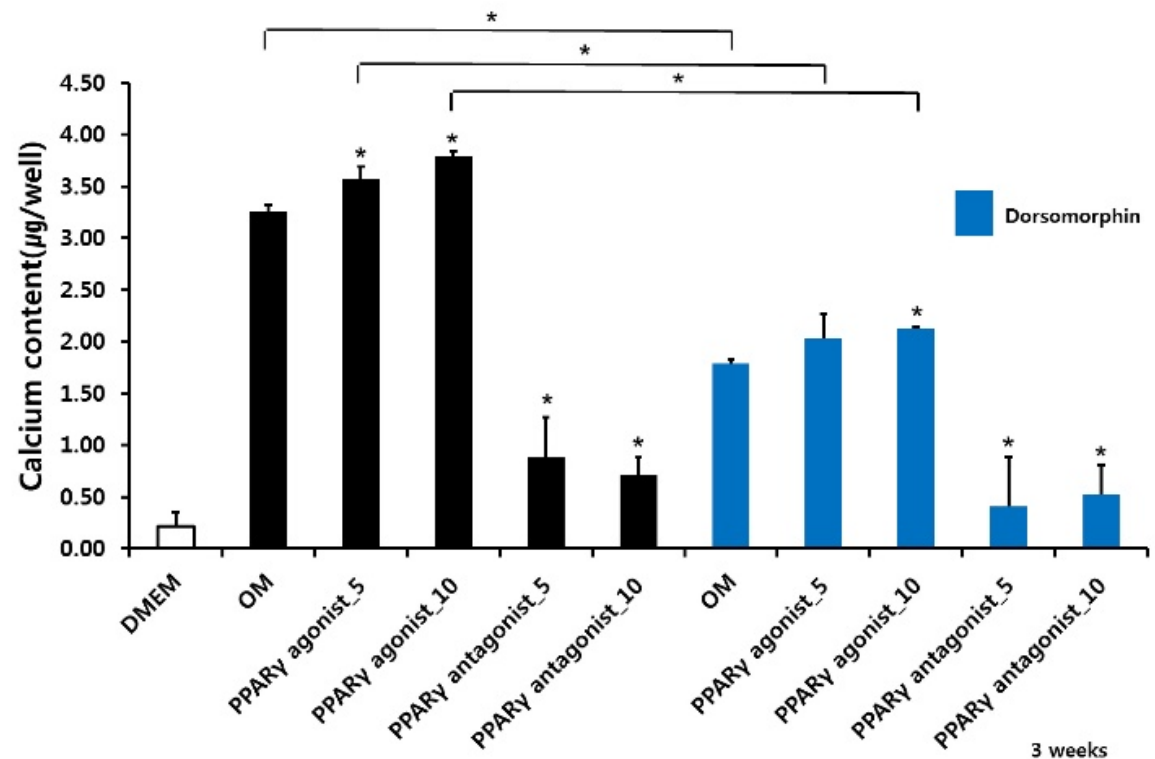

Figure 3. Effects of PPAR $\gamma$ agonist and antagonist and dorsomorphin on mineralization of periosteum-derived cells differentiated in osteoblastic induction media (OM). * $<0.05$ versus values observed in periosteum-derived cells cultured in OM without PPAR $\gamma$ agonist or antagonist treatment or versus values observed in periosteum-derived cells without dorsomorphin.

Quantitative RT-PCR analysis showed that treatment with the PPARY agonist significantly increased osteogenic induction medium-induced BMP-2 mRNA expression at 2 weeks. Conversely, the PPARY antagonist T0070507 clearly decreased osteogenic differentiation medium-induced BMP-2 upregulation throughout the 2-week experimental course (Fig. 4A). Similarly, western blot analysis indicated that BMP-2 expression was clearly induced by the PPARY agonist. The BMP-2 levels were also significantly increased in periosteum-derived osteoblastic cells treated with the PPARY agonist pioglitazone, compared with the levels in the cells cultured in osteogenic induction media without PPARY agonist at 2 weeks of culture. BMP-2 was also expressed in the periosteum-derived osteoblastic cells 
treated with PPARY antagonist; however, the expression level was markedly decreased in these cells at 2 weeks of culture compared to that in the cells cultured in osteogenic induction media without PPARY agonist or antagonist (Fig. 4B).

To visualize in vitro osteogenic phenotype of periosteum-derived osteoblastic cells treated with PPAR $\gamma$ agonist or antagonist, the cells were stained with antibody against BMP-2. At 2 weeks of culture, the cells treated with $10 \mu \mathrm{M}$ PPAR $\gamma$ agonist showed the brightest green color, compared with the cells cultured in osteogenic induction media without PPAR $\gamma$ agonist, whereas by comparison, BMP-2 expression in the cells treated with PPAR $\gamma$ antagonist was less evident in comparison (Fig. 4C). These results suggest that the clear expression of BMP-2 in the periosteum-derived cells treated with PPAR $\gamma$ agonist indicates that PPAR $\gamma$ agonist may encourage the osteogenic differentiation of the cells by activating BMP signaling in these cells.

A

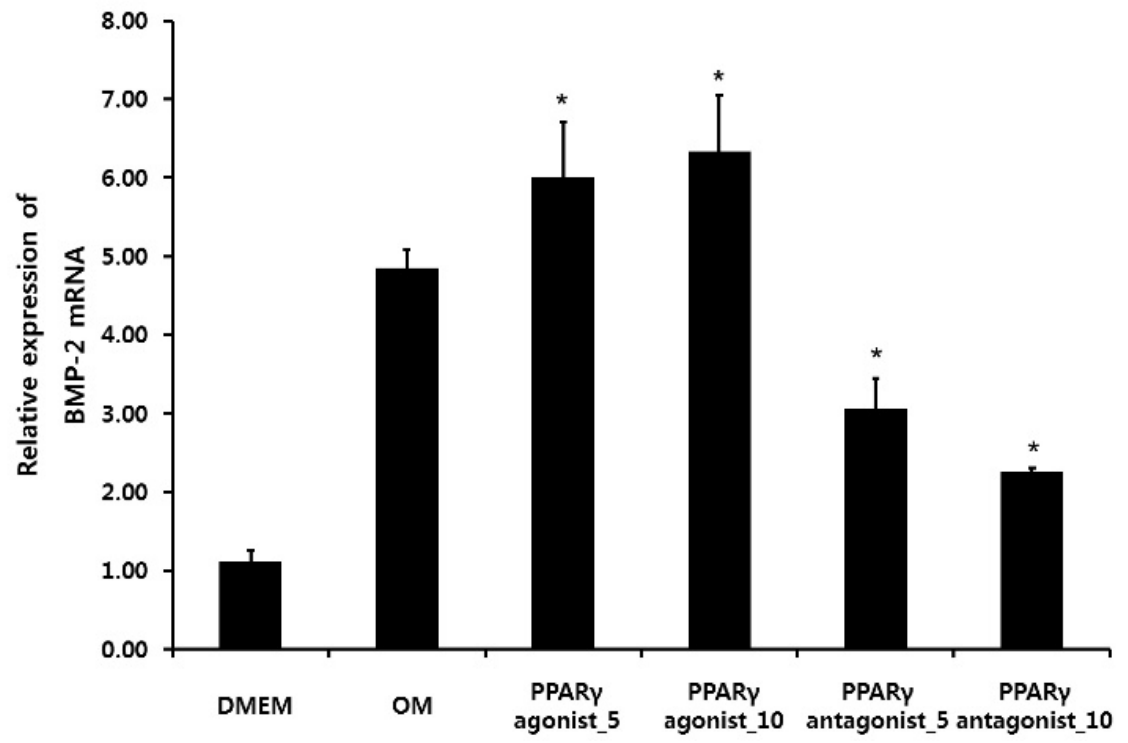

B
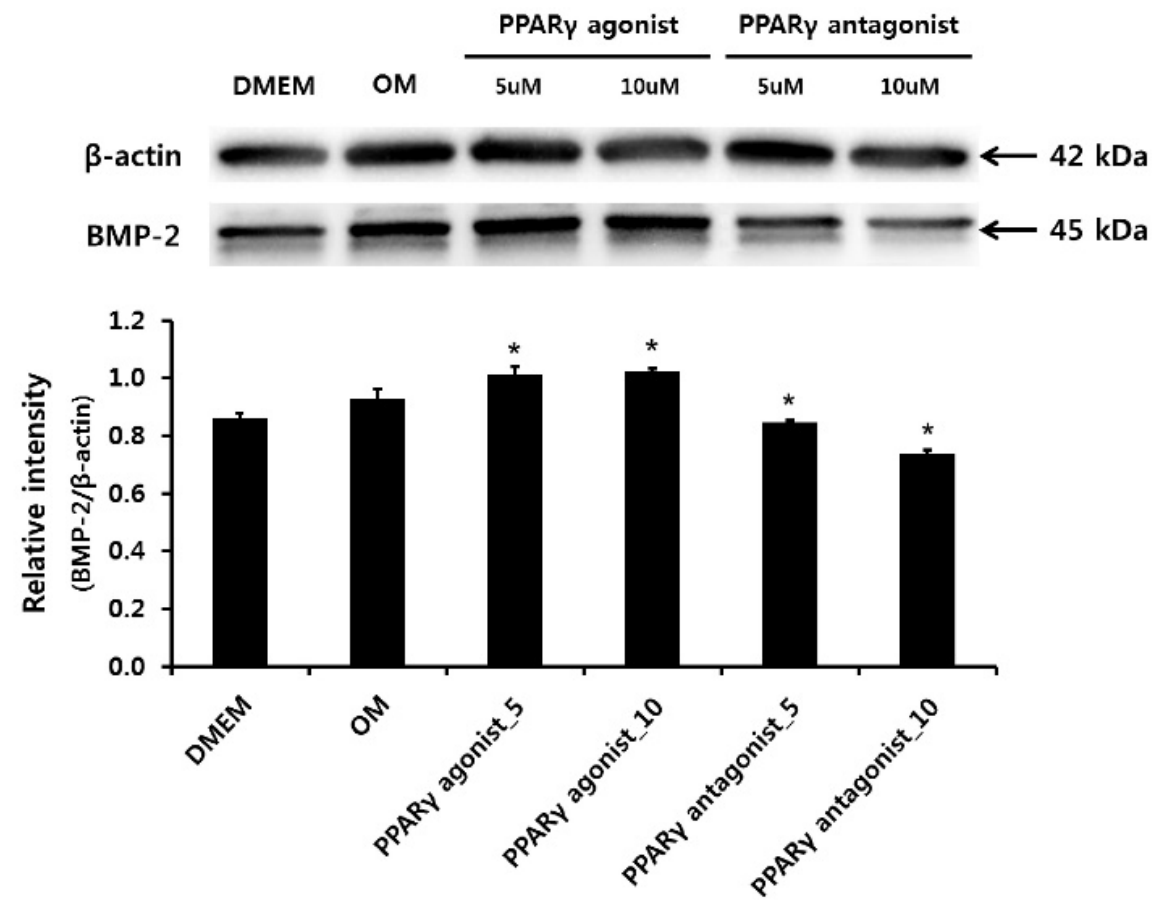
C

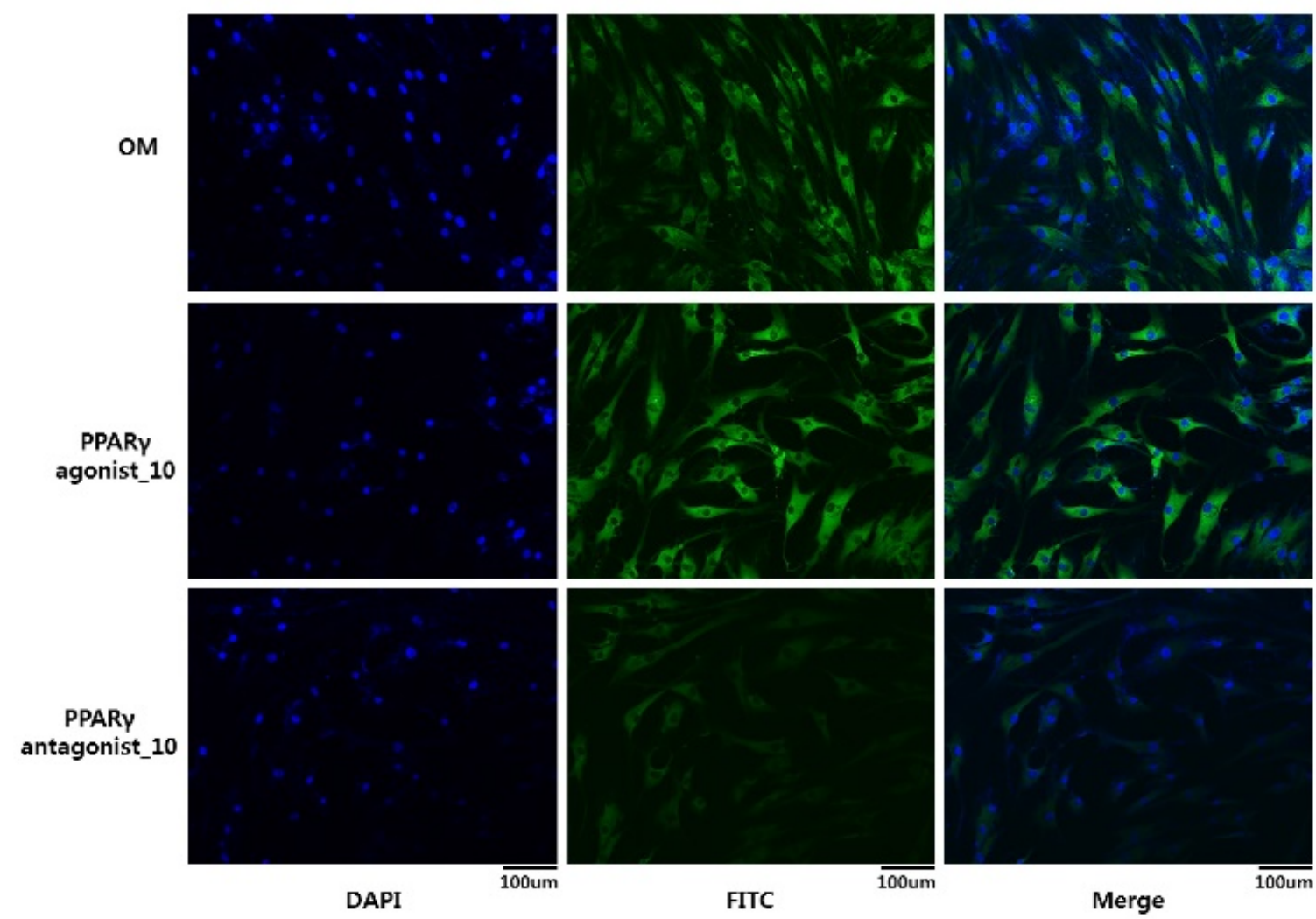

Figure 4. Effects of PPARy agonist or antagonist on expression of BMP-2 in the periosteum-derived osteoblastic cells. A: Quantitative RT-PCR analysis. B: Western blot analysis. C: Immunocytochemical observation. OM; osteogenic induction DMEM medium.

\section{Discussion}

PPARs are ligand-activated transcription factors that belong to the superfamily of nuclear hormone receptors and play important roles in cellular differentiation, development, and metabolism. Among PPARs, PPARY is activated by natural ligands such as polyunsaturated fatty acids and prostaglandin metabolites, and by synthetic ligands such as the anti-diabetic thiazolidinedione group, whose members include rosiglitazone, pioglitazone, and troglitazone. In relation to bone homeostasis, it is known that activation of PPARY by elevated serum lipids or by synthetic agonist ligands, can stimulate bone marrow adiposity and directly inhibits osteogenesis by diverting mesenchymal stem cells from the osteogenic phenotype to the adipogenic lineage in animals and humans [27-29].

Osteoblasts, adipocytes, and various other mesenchymal lineage cells originate from multipotent mesenchymal stem cells, which display differentiation plasticity. Although cell fate decision is regulated by multiple regulatory factors and signal pathways, gene regulation mediated by a transcriptional factor plays a critical role in cell fate determination. The transcriptional factor, which promotes one cell fate, is often found to actively represss the alternative fate. The reciprocal relationship between bone adiposity and bone mineral density has long been recognized. PPAR $\gamma$ is a prime regulator of adipogenesis and as such, the activation of PPAR $\gamma$ in precursors of nonadipogenic lineage cells triggers their transdifferentiation into adipocytes and shifts the bone marrow cell fate decision towards the adipogenesis $[4,26,30]$. However, the effects of PPAR $\gamma$ in ligands on the differentiation of cultured osteoprogenitor cells remain controversial [10-12]. In our previous study, we showed that PPAR $\gamma$ agonists stimulate osteoblastic differentiation of cultured human periosteum-derived cells and that PPAR $Y$ antagonists inhibit osteoblastic differentiation in the cells [19]. Moreover, in this study, PPAR $\gamma$ agonists enhanced the Runx2 transcriptional activity in periosteum-derived cells, whereas the PPAR $\gamma$ antagonists decreased the transcriptional activity of Runx2 in these cells. Given the transcriptional factor Runx2 plays a key role in osteoblast differentiation and function, these results suggest that the effects of PPAR $\gamma$ agonists on the in vitro osteoblastic 
differentiation of cultured human periosteal-derived cells also appear to be dependent on Runx2.

Although BMP signaling molecules modulate osteoblastic differentiation of osteoprecursor cells by enhancing osteoblast-related transcriptional factors, such as Runx2, and act as major osteogenic inducers, they may also influence adipocyte differentiation $[18,19]$. We therefore examined whether BMP signaling is involved in the effects of PPARY ligands on phenotypes of cultured human periosteum-derived osteoblastic cells by inhibiting BMP signaling with dorsomorphin. Pretreatment with dorsomorphin did not significantly affect ALP activity and mineralization in the periosteum-derived osteoblastic cells treated with a PPARY antagonist; however, dorsomorphin clearly decreased the ALP activity and mineralization in the cells treated with a PPARY agonist. These data suggest that the positive effects of PPARY agonists on the differentiation of cultured human periosteum-derived osteoblastic cells seem to be dependent on BMP signaling. We further examined whether the treatment of PPARY agonist or antagonist is involved in the expression of BMP-2 in the periosteum-derived osteoblasts. Among the various BMPs with osteogenic characteristics that have been discovered, BMP-2 is the most studied inducer of osteoblast differentiation that is strongly involved in committing mesenchymal stem cells towards the osteogenic lineage. In addition, BMP-2 has the highest osteogenic activity, was approved for human use by the US Food and Drug Administration (FDA), and has shown promising results for new bone formation in clinical practices [26,31]. In quantitative RT-PCR, western blot, and immunocytochemical analyses, BMP-2 was expressed in the periosteum-derived osteoblastic cells treated with PPARY agonist and antagonist. However, the expression was markedly higher in the cells treated with PPARY agonist than in those treated with PPARY antagonist or cultured in osteogenic induction media without PPARY agonist or antagonist. These results also suggest that the effects of PPARY agonists on the enhanced osteogenic phenotypes of cultured human periosteum-derived osteoblasts are regarded to be dependent of BMP signaling.

To our knowledge, evidence regarding the positive effects of PPARY agonists on cultured human osteoprecursor cells has been limited. Although the mechanism that explains the effects of PPARy agonist on the BMP signaling during osteoblastic differentiation of periosteum-derived cells is not fully clarified and needs further study, the primary findings of this study indicate that the positive effects of PPARY agonists on the osteogenic phenotypes of cultured human periosteum-derived cells seem to be dependent of BMP signaling. Also, further study is needed to elucidate the relationship between molecular signaling mechanisms and the effects of PPARY antagonists during differentiation of human periosteum-derived osteoblasts.

\section{Acknowledgements}

This research was supported by Basic Science Research Program through the National Research Foundation of Korea (NRF) funded by the Ministry of Education, Science and Technology (NRF-2014R1A1A2055288). This study was also supported by a grant of the Korean Health Technology R\&D Project, Ministry of Health \& Welfare, Republic of Korea (HI13C1596, HI15C0607).

\section{Competing Interests}

The authors have declared that no competing interest exists.

\section{References}

1. Schilling T, Nöth U, Klein-Hitpass L, Jakob F, Schütze N. Plasticity in adipogenesis and osteogenesis of human mesenchymal stem cells. Mol Cell Endocrinol. 2007;271(1-2):1-17.

2. Takada I, Suzawa M, Matsumoto K, Kato S. Suppression of PPAR transactivation switches cell fate of bone marrow stem cells from adipocytes into osteoblasts. Ann N Y Acad Sci. 2007;1116:182-195.

3. Muruganandan S, Roman AA, Sinal CJ. Adipocyte differentiation of bone marrow-derived mesenchymal stem cells: cross talk with the osteoblastogenic program. Cell Mol Life Sci. 2009;66(2):236-253.

4. Liu LF, Shen WJ, Zhang ZH, Wang LJ, Kraemer FB. Adipocytes decrease Runx2 expression in osteoblastic cells: roles of PPARY and adiponectin. J Cell Physiol. 2010;225(3):837-845.

5. Zhuang H, Zhang X, Zhu C, Tang X, Yu F, Shang GW, Cai X. Molecular Mechanisms of PPAR- $\gamma$ Governing MSC Osteogenic and Adipogenic Differentiation. Curr Stem Cell Res Ther. 2016;11(3):255-264.

6. Grey A, Bolland M, Gamble G, Wattie D, Horne A, Davidson J, Reid IR. The peroxisome-proliferatoractivated receptor-gamma agonist rosiglitazone decreases bone formation and bone mineral density in healthy postmenopausal women: a randomized, controlled trial. J Clin Endocrinol Metab. 2007:92(4):1305-1310.

7. Gruntmanis U, Fordan S, Ghayee HK, Abdullah SM, See R, Ayers CR, McGuire DK. The peroxisome proliferator-activated receptor-gamma agonist rosiglitazone increases bone resorption in women with type 2 diabetes: a randomized, controlled trial. Calcif Tissue Int. 2010;86(5):343-349.

8. Takada I, Makishima M. PPARY ligands and their therapeutic applications: a patent review (2008 - 2014). Expert Opin Ther Pat. 2015;25(2):175-191.

9. Marciano DP, Kuruvilla DS, Boregowda SV, Asteian A, Hughes TS, Garcia-Ordonez R, Corzo CA, Khan TM, Novick SJ, Park H, Kojetin DJ, Phinney DG, Bruning JB, Kamenecka TM, Griffin PR. Pharmacological repression of PPARy promotes osteogenesis. Nat Commun. 2015; 6:7443.

10. Jackson SM, Demer LL. Peroxisome proliferator-activated receptor activators modulate the osteoblastic maturation of MC3T3-E1 preosteoblasts. FEBS Lett. 2000;471(1):119-124.

11. Kang $Q$, Song WX, Luo $Q$, Tang N, Luo J, Luo X, Chen J, Bi Y, He BC, Park JK, Jiang W, Tang Y, Huang J, Su Y, Zhu GH, He Y, Yin H, Hu Z, Wang Y, Chen L, Zuo GW, Pan X, Shen J, Vokes T, Reid RR, Haydon RC, Luu HH, He TC. A comprehensive analysis of the dual roles of BMPs in regulating adipogenic and osteogenic differentiation of mesenchymal progenitor cells. Stem Cells Dev 2009;18(4):545-559.

12. Yu WH, Li FG, Chen XY, Li JT, Wu YH, Huang LH, Wang Z, Li P, Wang T, Lahn BT, Xiang AP. PPARY suppression inhibits adipogenesis but does not promote osteogenesis of human mesenchymal stem cells. Int J Biochem Cell Biol. 2012;44(2):377-384.

13. Onishi M, Fujita $Y$, Yoshikawa $H$, Yamashita T. Inhibition of Rac1 promotes BMP-2-induced osteoblastic differentiation. Cell Death Dis. 2013;4:e698

14. Addison WN, Fu MM, Yang HX, Lin Z, Nagano K, Gori F, Baron R. Direct Transcriptional Repression of Zfp423 by Zfp521 Mediates a Bone Morphogenic Protein-Dependent Osteoblast versus Adipocyte Lineage Commitment Switch. Mol Cell Biol. 2014;34(16):3076-3085.

15. Lin GL, Hankenson KD. Integration of BMP, Wnt, and Notch signaling pathways in osteoblast differentiation. J Cell Biochem. 2011;112(12):3491-3501. 
16. Zouani OF, Rami L, Lei Y, Durrieu MC. Insights into the osteoblast precursor differentiation towards mature osteoblasts induced by continuous BMP-2 signaling. Biol Open. 2013;2(9):872-881.

17. Hah YS, Joo HH, Kang YH, Park BW, Hwang SC, Kim JW, Sung IY, Rho GJ, Woo DK, Byun JH. Cultured human periosteal-derived cells have inducible adipogenic activity and can also differentiate into osteoblasts in a perioxisome proliferator-activated receptor-mediated fashion. Int J Med Sci. 2014;11(11):1116-1128

18. Huang $\mathrm{H}$, et al. BMP signaling pathway is required for commitment of C3H10T1/2 pluripotent stem cells to the adipocyte lineage. Proc Natl Acad Sci U S A. 2009;106(31):12670-12675.

19. Bowers RR, Jae Kim JW, Otto TC, Lane MD. Stable stem cell commitment to the adipocyte lineage by inhibition of DNA methylation: Role of the BMP-4 gene. Proc Natl Acad Sci U S A. 2006;103(35):13022-13027.

20. Zhang Y, Xie RL, Croce CM, Stein JL, Lian JB, van Wijnen AJ, Stein GS. A program of microRNAs controls osteogenic lineage progression by targeting transcription factor Runx2. Proc Natl Acad Sci U S A. 2011;108(24): 9863-9868.

21. Ge C, Cawthorn WP, Li Y, Zhao G, Macdougald OA, Franceschi RT. Reciprocal Control of Osteogenic and Adipogenic Differentiation by ERK/MAP Kinase Phosphorylation of Runx2 and PPARy Transcription Factors. J Cell Physiol. 2016;231(3):587-596.

22. Phimphilai M, Zhao Z, Boules H, Roca H, Franceschi RT. BMP signaling is required for RUNX2-dependent induction of the osteoblast phenotype. J Bone Miner Res. 2006;21(4):637-646.

23. Horbelt D, Boergermann JH, Chaikuad A, Alfano I, Williams E, Lukonin I, Timmel T, Bullock AN, Knaus P. Small molecules dorsomorphin and LDN-193189 inhibit myostatin/GDF8 signaling and promote functional myoblast differentiation. J Biol Chem. 2015;290(6):3390-3404.

24. Yu PB, Hong CC, Sachidanandan C, Babitt JL, Deng DY, Hoyng SA, Lin HY, Bloch KD, Peterson RT. Dorsomorphin inhibits BMP signals required for embryogenesis and iron metabolism. Nat Chem Biol. 2008:4(1):33-41.

25. Lee JH, Kim SW, Kim UK, Oh SH, June-Kim S, Park BW, Kim JH, Hah YS, Kim DR, Rho GJ, Maeng GH, Jeon RH, Lee HC, Kim JR, Kim GC, Byun JH. Generation of osteogenic construct using periosteal-derived osteoblasts and polydioxanone/ pluronic F127 scaffold with periosteal-derived CD146 positive endothelial-like cells. J Biomed Mater Res A. 2013;101(4):942-953.

26. Kang H, Hata A. The role of microRNAs in cell fate determination of mesenchymal stem cells: balancing adipogenesis and osteogenesis. BMB Rep. 2015;48(6):319-323

27. Nallamshetty S, Le PT, Wang H, Issacsohn MJ, Reeder DJ, Rhee EJ, Kiefer FW, Brown JD, Rosen CJ, Plutzky J. Retinaldehyde dehydrogenase 1 deficiency inhibits PPAR $\gamma$-mediated bone loss and marrow adiposity. Bone. 2014;67:281-291.

28. James AW, Shen J, Khadarian K, Pang S, Chung G, Goyal R, Asatrian G, Velasco O, Kim J, Zhang X, Ting K, Soo C. Lentiviral delivery of PPARY shRNA alters the balance of osteogenesis and adipogenesis, improving bone microarchitecture. Tissue Eng Part A. 2014;20(19-20):2699-2710.

29. Kawai M, Rosen CJ. PPARY: a circadian transcription factor in adipogenesis and osteogenesis. Nat Rev Endocrinol. 2010;6(11):629-636.

30. Takada I, Yogiashi Y, Kato S. Signaling Crosstalk between PPARY and BMP2 in Mesenchymal Stem Cells. PPAR Res. 2012;2012:607141.

31. Visser R, Arrabal PM, Becerra J, Rinas U, Cifuentes M. The effect of an rhBMP-2 absorbable collagen sponge-targeted system on bone formation in vivo. Biomaterials. 2009;30(11):2032-2037. 